\title{
MODIFICATION OF STRUCTURE OF THE SURFACE OF STEEL (XTC) AS A RESULT OF INFLUENCES OF HIGH-CURRENT ELECTRON BEAM
}

\author{
E.M. Prokhorenko ${ }^{1}$, V.V. Lytvynenko ${ }^{1}$, O.A. Melyakova', Yu.F. Lonin ${ }^{2}$, A.G. Ponomarev ${ }^{2}$, \\ V.T. Uvarov ${ }^{2}$, N.A. Shul'gin ${ }^{2}$, T.G. Prokhorenko ${ }^{3}$ \\ ${ }^{1}$ Institute of Electrophysics and Radiation Technologies, Kharkiv, Ukraine; \\ ${ }^{2}$ NSC “Kharkov Institute of Physics and Technology”, Kharkiv, Ukraine; \\ ${ }^{3}$ Kharkov National Automobile and Highway University, Kharkiv, Ukraine \\ E-mail:forshad58@gmail.com
}

\begin{abstract}
The steel surface (ХГC) was irradiated with a high-current electron beam. A high-current electron beam was obtained in the TEMP-A accelerator. Steel samples were made from drum mill balls. The balls had varying degrees of wear. The mechanical and microstructural characteristics were studied. Applied methods: measurement of hardness, tensile strength, fractographic and metallographic analysis. An increase in hardness was found for all samples. An increase in the surface hardness of the samples occurred as a result of the conversion of austenite to martensite and lower bainite. A significant effect on the increase in surface hardness of the samples is also exerted by the process of the appearance of carbides.
\end{abstract}

PACS: 87.55N, 07.05.Tp, 44.90.+c, 61.80.Fe, 81.40.Wx

\section{INTRODUCTION}

The issue of power generation is important for all areas of production. A significant role in the generation of electricity is made by thermal power-stations. Many of them use coal as fuel. For its use with maximum efficiency, it is necessary to carry out preliminary preparation. Among the processes for preparing coal, there is a process of grinding it to a state of dust. This process allows you to increase the efficiency of heat emissions.

Coal grinding is carried out on ball drum mills (BDM) due to the impact of metal balls on coal. In this case, the balls wear out. Erasing and breaking balls reduces time of their exploitation.

During work of drum mills a wear of balls is found from expression [1]:

$$
G_{b}=D_{\text {real }} \cdot K_{f} \cdot \sum B_{f},
$$

$G_{b}$-is the total fuel consumption; $D_{\text {real }}$ - the actual value of the specific wear of the balls. This value is directly proportional to the hardness of the surface of the ball. Therefore, the task of increasing the strength of the balls and the hardness of their surface requires a solution.

The increase of hardness of balls decides economic problems. Social problems decide also. Thermal powerstations are objects which largely render negative influence on an ecological situation.

Among the negative factors are: the emission into the atmosphere of a significant amount of coal combustion products, the appearance of ash dumps, local increase of the temperature field. It only is insignificant part of influence of thermal energy on an environment. The increase of hardness of balls which are used in drum mills allows getting more high-quality grinding of coal. This increases the efficiency of its combustion. This reduces fuel consumption, reduces the amount of unburned particles, and improves the quality of ash. Consequently, the load on the smoke gases cleaning system is reduced; the amount of ash and the pollution of its dumps are reduced.
All this in a complex solves separate ecological questions. That in turn makes it possible to solve social problems.

Use balls which were made from carbon instrumental steels. Apply different methods for the increase of hardness of surface of balls. Cementation of surface, treatment of surface different methods is produced for this purpose. High carbon steels are used.

One way to harden a surface is to modify it when processing a metal surface with beams of accelerated particles. We can single out the problem of using highcurrent electron beams (HCEB) [2, 3].

The method of irradiation of materials with a HCEB is progressive and unique [4-6]. Treatment of surface of material is produced out in various modes and with different energy characteristic.

In various experimental setups, the pulse duration can vary in a wide time range (from $10^{-8}$ to $10^{-5} \mathrm{~s}$ ). The beam energy also varies in a wide range (tens of $\mathrm{keV}-$ several MeV). Current densities up to $10^{4} \mathrm{~A} / \mathrm{cm}^{2}$.

The change of parameters of beam enables to get the different types of modification of surface.

The aim of this work was to conduct research on the effectiveness of using a HCEB to for modification of surface of steel of the (ХГС) type.

Perform an analysis of changes in the structure of the steel surface (ХГC) that occurred as a result of the modification. Determine the degree of hardening of the surface of the ball.

To finalize the methods of IR-radiometric diagnostics while monitoring the thermal effect of a HCBE on the target.

The work was carried out in several directions. Among them, the development of technology for irradiating samples with a HCBE. In this case, hardening of the surface of the balls used in drum mills was carried out.

The application of this technique allows increasing the life of the balls, which increases the efficiency of the drum mills. Technology of irradiation of surface can be applied on an industrial scale. 
For control of the temperature field which changes in the process of irradiation of standards the method of IR-radiometric diagnostics was used [6-8].

Using infrared radiometric monitoring, it becomes possible in real time to monitor changes in the temperature field on surface the target.

This allows you to perform operative intervention in the irradiation process. This makes it possible to obtain the necessary modification of the target surface.

\section{MATERIALS AND METHODS}

Work on the irradiation of targets was carried out on an electron accelerator TEMP-A [9] (NSC "Kharkov Institute of Physics and Technology").

The beam had such parameters. Beam diameter $45 \mathrm{~mm}$. Electron energy $\sim 350 \mathrm{keV}$. The impulse had a duration of $\tau_{\mathrm{p}} \sim 5 \mu \mathrm{s}$. The impulse duration was determined from the graph of the oscilloscope (Fig. 1). The voltage was measured based on the upper graph on the oscilloscope.
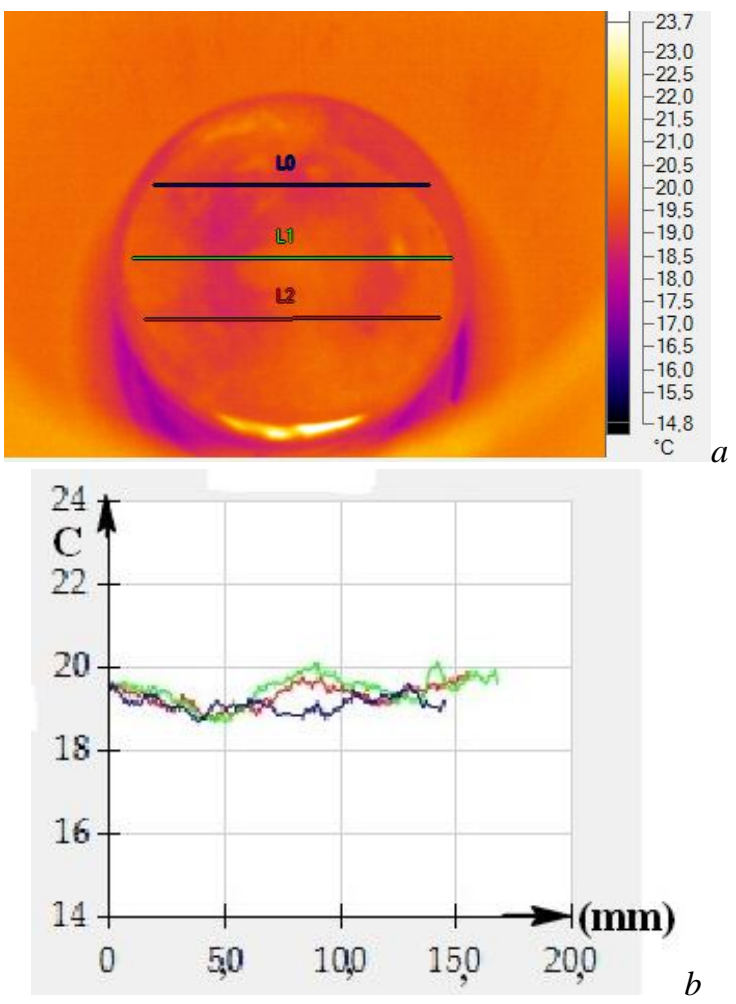

Fig. 1. The results of thermographic survey:

a-image of the thermal field on the surface;

$b$ - graphs of temperature changes on the target surface along the lines $L_{0}, L_{1}, L_{2}$

When measuring voltage, a non-inductive voltage divider was used. The beam current was $2 \mathrm{kA}$. Measuring of current was conducted by the belt of Rogovskogo, which was fastened round the rod of the sample holder (middle graph).

The beam intensity was distributed by law of Gausse. Peak of fluence - approximately $250 \mathrm{~J} / \mathrm{cm}^{2}$. The vacuum in the irradiation chamber was $10^{-5}$ Torr.

The electron beam is generated as a result of explosive emission from the edge cathode. The cathode has a cylindrical shape.

An electron beam is formed in crossed electric and magnetic fields and has a tubular shape. The beam shape and wall thickness depends on the size of the fields, the angle between the magnetic and electric fields, sizes of chamber of transporting, and many other parameters.

In this case, it is possible sharply expressed tubular bunch with the thickness of wall in a few millimeters.

Control of changes of the temperature field was conducted by the device of Ti-814. He executes measurings in the spectral range of $7.5 \ldots 14 \mu \mathrm{m}$. Temperature sensitivity $0.08{ }^{\circ} \mathrm{C}$.

The Fluke Ti-32 thermal imaging device was also used. Its temperature sensitivity is $0.05{ }^{\circ} \mathrm{C}$. The device operates both in the infrared and in the visible range. There is possibility to execute mixing of images. This allows you to control the temperature field of the target during irradiation. The results of the thermographic survey are shown in Fig. 1.

Fig. 1 shows the thermogram of the target $(a)$ and graphs of changes in the temperature field $(b)$ during irradiation. The straight lines $\mathrm{L}_{0}, \mathrm{~L}_{1}, \mathrm{~L}_{2}$ allow us to determine the numerical values of the temperature field. Graphs of changes in the temperature field show that heating occurs uniformly over the entire surface of the target.

Targets which are made from steel of brand of ХГС were exposed to HCEB. Steel billets were cut from balls. Some of the balls were not in use (diameter $40 \mathrm{~mm}$ ). Several balls were already in operation and had varying degrees of wear (diameter 35, $20 \mathrm{~mm}$ )

The last was the ball, after a full cycle of work in a ball mill (15 $\mathrm{mm}$ diameter). This selection of balls made it possible to obtain a whole series of targets. We have a full range of damage that the balls received as a result of exploitation.

Steel (XГC) is a carbon alloy steel. Steel products are designed for use in environments with elevated temperatures. Steel contains in its composition such additives (Table).

Additions of elements in steel of ХГС

\begin{tabular}{|c|c|c|c|c|c|}
\hline & $\mathrm{C}, \%$ & $\mathrm{Si}, \%$ & $\mathrm{Mn}, \%$ & $\mathrm{Cr}, \%$ & $\mathrm{~V}, \%$ \\
\hline St. & $0.95 \ldots$ & $0.4 \ldots$ & $0.85 \ldots$ & $1.3 \ldots$ & $0.15 \ldots$ \\
ХГС & 1.05 & 0.7 & 1.25 & 1.65 & 0.3 \\
\hline
\end{tabular}

Possible additives (not more than $0.03 \%$ ) of sulfur and phosphorus. Also in the composition of steel (ХГС) there is molybdenum, tungsten, nickel, copper. Their total amount does not exceed $0.3 \%$.

\section{CONDUCTING EXPERIMENTS AND DISCUSSION OF RESULTS}

During irradiation, the surface hardness of the ball changed. Because this is an important parameter, then research of his change was conducted. The detailed technology of preparation of standards and lead through of measuring is given in [1].

Hardness was measured using a PMT-3 hardness tester. On the first stage, measuring of hardness of surface of balls which had a different degree of wear were executed. For this, the balls were extracted from the drum mill during operation. For a new ball (diameter $40 \mathrm{~mm}$ ), the hardness was $10000 \mathrm{MPa}$. 
For a ball with a diameter of $35 \mathrm{~mm}-8500 \mathrm{MPa}$, $7300 \mathrm{MPa}$ for a ball with a diameter of $20 \mathrm{~mm}$. And the minimum values of hardness were $6700 \mathrm{MPa}$ for a ball with a diameter of $15 \mathrm{~mm}$. This is a ball after being removed from a drum mill. Hardness deviations did not exceed values $\pm 50 \mathrm{MPa}$.

However, on the surface of all the balls that were in operation, several areas with lower hardness were found.

Two areas with a hardness of $7800 \mathrm{MPa}$ were found on the surface of a ball with a diameter of $35 \mathrm{~mm}$. On the surface of a ball with a diameter of $20 \mathrm{~mm}$ there are four areas with a hardness of $6800 \mathrm{MPa}$. On the surface of a ball with a diameter of $15 \mathrm{~mm}$ there are four areas with a hardness of $6300 \mathrm{MPa}$.

Apparently, these areas are centers of the origin of future destruction [1]. These areas were formed as a result of summing up the many strokes to which the ball is subjected during operation.

The balls were then cut into pucks $2 \mathrm{~mm}$ thick. The hardness in the central part of the balls was measured. For all balls, regardless of the degree of wear and time of exploitation, it had a value of about $9300 \mathrm{MPa}$.

After that, all samples were irradiated with a HCEB at the TEMP-A accelerator. The use of HCEB makes it possible to change the surface structure with a high rate of energy exposure, to carry out operational control of changes.

As a result of exposure to a HCEB, a number of processes occur on the surface. This is a quick heating of the target surface due to the high energy density, high temperature surface melting and rapid cooling. In this case, part of the target material evaporates ablation, and the formation of a plasma cloud above the surface.

As a result of irradiation of the target with a HCEB, its modification occurs. This is due to the fact that when the target is processed by HCEB, is heated surface very quickly. As a result of this heating in the surface layer, molten metal regions are formed.

In this case, there is a sharp crystallization of separate areas of the melt on a colder substrate. This process is accompanied by the appearance of various effects.

We will mark that if the thickness of the target is less than three depths of penetration of the beam, then its destruction is possible. As a result of irradiation of the sample, possibly, appearance of a few areas with a different structure. Upper zone on the surface of the sample is a quenching zone.

Under the tempering area is a zone that has been subjected to a combined effect. Several factors work in it: thermal exposure, melting, evaporation, and material ejection due to ablation.

Thermal exposure also has a dual nature. On the one hand - a sharp heating, on the other - a sharp cooling due to the presence of a cold base.

The third zone - is an area that has been subjected to dynamic loadings. This area is limited to unirradiated material. The upper regions appeared as a result of the sharp heating and of the sharp cooling.

The lower area is formed as a result of influence of shock waves and the formation of defects. Defects appear due to emissions of the molten metal from the surface, due to inhomogeneous evaporation.

Also, the appearance of shock waves occurs due to the inhomogeneity of surface heating and uneven cooling of the base.

By selecting the parameters of a HCEB, it becomes possible to harden the target surface [10-15]. Several mechanisms influence the effect of surface hardening and increase in hardness.

In particular, it is transformation of material of surface to the martensite [11], the formation of various oxides [12], surface carbonization [13-15], purification from various inclusions by evaporation [13-16], and ablation effects [14-17]. We will mark that during cleaning; inclusions evaporate from the surface, the temperature of which is higher than the melting temperature of the entire material.

The amount of sulfur inclusions was found to decrease. Sulfur inclusions reduce the hardness of steel [17]. After irradiation, a finely grained structure is formed. A phase transition and structural changes are possible. The mechanical surface characteristics and corrosion resistance are improved [10-17].

Surface treatment changes the appearance of the surface (Fig. 2).

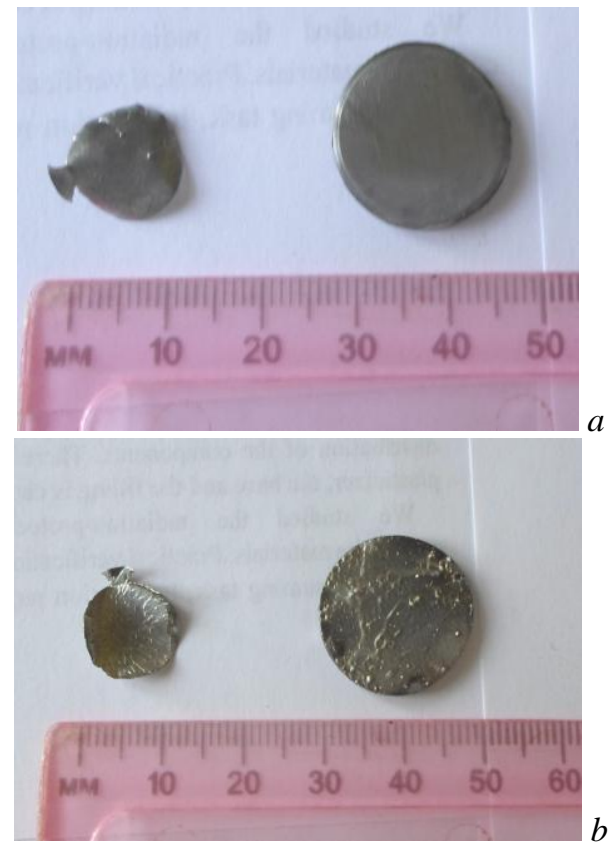

Fig. 2. Pictures of the pucks a-before processing on the accelerator

$b$-after irradiation at the TEMP-A accelerator

In Fig. 2,a we observe smooth surfaces. The puck, which is shown on the right, is cut from a ball with a diameter of $20 \mathrm{~mm}$. Puck on the left, from a ball with a diameter of $15 \mathrm{~mm}$. In Fig. 2,b shows the puck after irradiation. The surfaces of the puck have a molten structure. Traces of exposure to a HCEB are observed on the surface.

The surface hardness of the pucks was measured both before and after irradiation. The measurement results are presented in the graph of Fig. 3. 


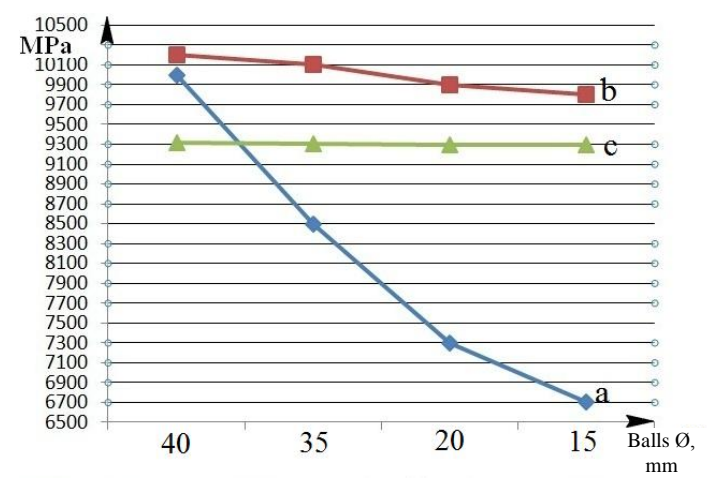

Fig. 3. Curves of changes in the hardness of balls: $\boldsymbol{a}$ - on the surface during operation; $\boldsymbol{b}$ - on the surface after irradiation; $\boldsymbol{c}$ - in the central part of the ball

On the horizontal axis are the diameters of the balls. Ball with a diameter $40 \mathrm{~mm}$ in exploitation was not. A ball with a diameter of $15 \mathrm{~mm}$ worked the entire grinding cycle and was removed from the drum mill. All of these samples were not irradiated. The hardness values for these samples are shown in Fig. 3 (curve $\boldsymbol{a}$, blue color, marker - rhombus).

As a result of irradiation, the hardness of the surface of the balls has changed. Hardness values after irradiation are shown in Fig. 3 (curve $\boldsymbol{b}$, red, marker square). An increase in surface hardness was found for all samples. For the new ball, the hardness was $10200 \mathrm{MPa}$, which is much more than the normative requirements.

A ball with a diameter of $35 \mathrm{~mm}$ had a hardness value of $10100 \mathrm{MPa}$. For a ball with a diameter of $20 \mathrm{~mm}$, the hardness value is $9900 \mathrm{MPa}$. And for a ball with a diameter of $15 \mathrm{~mm}$, the hardness value is $9800 \mathrm{MPa}$. For all samples, surface hardening occurred as a result of irradiation.

The degree of hardening is different for balls with varying degrees of wear. The new ball had a hardness increase of only $200 \mathrm{MPa}$. Whereas a ball with a diameter of $35 \mathrm{~mm}$ is already $1500 \mathrm{MPa}$. The maximum increase in hardness was found for the ball, which worked, in a mill - $2100 \mathrm{MPa}$.

This is due to the fact that after extraction it had minimal strength. The greater the wear of the ball, the higher the degree of hardening. The increase of hardness took place to the certain level.

The hardness in the central part of the balls remained unchanged throughout the grinding process and subsequent irradiation (curve $\boldsymbol{c}$, green, marker triangle).

Its value was in the district of $9300 \mathrm{MPa}$. The measurement of the hardness of the ball in its central part is carried out in accordance with the requirements of GOST.

The mechanism of increase of hardness is identical. We suppose that hardness was increased due to fusion of superficial layer and his recrystallization. Thus, it is possible to do supposition, that in the process of exploitation of balls their phase structure suffered changes. Accordingly, the melt and recrystallization proceeded in the same mode.
One of characteristics of solid is plasticity of material. For research of this parameter measurings were executed on a break machine. The results of measurings are presented on the graphs of Fig. 4.

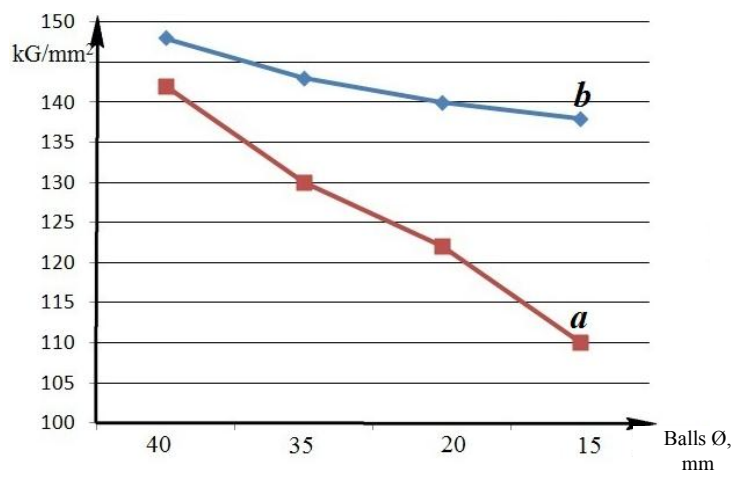

Fig. 4. Graphs of change of the attached tension.

Test on a break machine: $\boldsymbol{a}$ - tensions before irradiation; $\boldsymbol{b}$ - tensions after irradiation

A decrease in the plasticity of the samples, which occurred as a result of irradiation, was detected. To break the samples requires a greater application of forces. A sample made from a new ball $(\varnothing 40 \mathrm{~mm})$, after irradiation, was destroyed at a force of $148 \mathrm{~kg} / \mathrm{mm}^{2}$ Before irradiation, a force of $142 \mathrm{~kg} / \mathrm{mm}^{2}$ was required. In the case of a ball with a diameter of $20 \mathrm{~mm}$, the values of the applied forces are 140 and $122 \mathrm{~kg} / \mathrm{mm}^{2}$, accordingly.

For a ball with a diameter of $12 \mathrm{~mm}$, the tensile strength after irradiation is $138 \mathrm{~kg} / \mathrm{mm}^{2}$. And the tensile strength before treatment was $110 \mathrm{~kg} / \mathrm{mm}^{2}$.

To study changes in the structure of sample materials, surface studies in the optical range were performed. In Fig. 5 photos of the surfaces of the balls are shown.

To study changes in the structure of sample materials, surface studies in the optical range were performed. In Fig. 5 photos of the surfaces of the balls are shown.

Image analysis was performed using reference images given $[18,19]$. Since steel has $0.95 \ldots 1.05 \%$ carbon in its composition, it belongs to hypereutectoid steel. Therefore, all changes must be considered taking into account phase transitions in the hypereutectoid area.

The figure (see Fig. 5,a) shows a photo of the steel surface of an unirradiated ball. Ball was not in use (new ball). Various phases of iron are observed. The structure may be invariant. Those it incorporates ferrite, cementite, austenitic steel. The main phase on the surface is austenitic steel (grains 1).

It was formed as a result of cooling of hypereutectic steel melt. The remains of ferrite grains were discovered (points 2). This is possible in areas where the polymorphic transformation $\boldsymbol{\gamma} \rightarrow \boldsymbol{\alpha}$ occurred during cooling, that is, in a wide temperature range. In this case, a redistribution of carbon between the grains of ferrite and austenite occurred. 


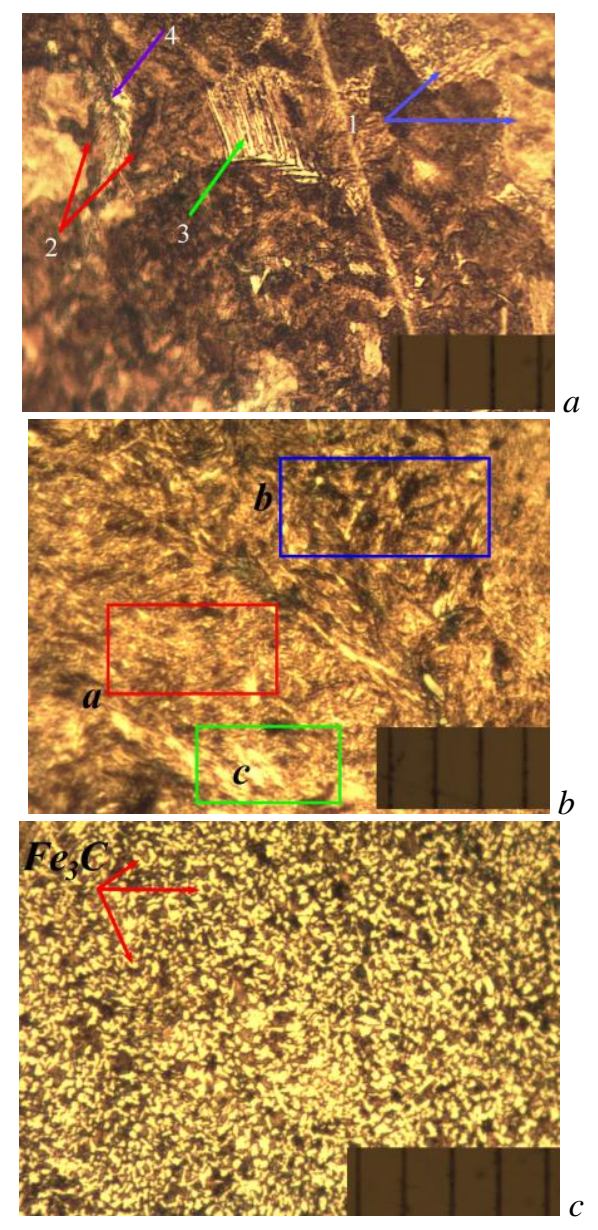

Fig. 5. Photos of the surface of the ball: $a-a$ new ball before irradiation;

$b$ - ball after irradiation, target thickness $2 \mathrm{~mm}$ (it was in exploitation); $c$ - ball after irradiation, target thickness $0.7 \mathrm{~mm}$ (it was in exploitation)

In our case, austenite predominates. The amount of ferrite is negligible. An almost complete conversion of ferrite has occurred. This transformation was instrumental in the increase of hardness of steel.

One perlite area was also detected (area 3). Perlite is a lamellar structure that consists of alternating plates of ferrite and cementite. Perlite stood out along the grain boundaries. Cementite has a significant amount of carbon in its composition.

The eutectoid transformation of austenitic steel occurs at a temperature of $727^{\circ} \mathrm{C}$. With decreasing melt temperature, the amount of perlite and cementite increases. The allocation of secondary cementite occurs along the boundaries of former grains of austenitic steel.

Secondary cementite is exuded in the form of needles that are specifically oriented relative to grains of austenitic steel. Formation of secondary cementite in the form of needles makes steel more brittle. Only one area of secondary cementite is observed in the photograph (4). The area consists of several needles of secondary cementite. Therefore, the steel is quite hard. It all behaves to steel.

In Fig. 5,b is a photograph of the surface of the ball. The ball worked in a mill. The thickness of the target is $2 \mathrm{~mm}$. There is a structure that corresponds to three types of steel. The lower left part $(\boldsymbol{a})$ is martensite, the upper right part $(\boldsymbol{b})$ - is lower bainite.
There is also residual austenite $(\boldsymbol{c})$. Martensite is well-organized solid solution of carbon in $\boldsymbol{\alpha}$-iron. Its hardness is higher than austenite. The amount of carbon in martensite may be the same as in the initial austenite. It is necessary to mark the characteristic feature of martensite nucleation from an austenite.

The martensitic transformation from austenite begins when the melt reaches a temperature that corresponds to a certain point $\left(\boldsymbol{M}_{\boldsymbol{s}}\right)$. Growth of martensite is carried out due to appearance of new crystals, but not due to growth of old crystals which have a non-coherent structure. And the lower the temperature, the more martensite is formed.

The main requirement for the occurrence of martensitic transformations is the presence of a constant outflow of heat. In our case, this is done. We have a melt that heats up quickly. The melt is on a cold base.

Due to the mass of the substrate, fast heat is removed from the crystallization area. Thus, the conditions for obtaining martensite are realized. At the initial stage of cooling the melt, the martensitic transformation works, and then the substrate is heated. And the lower bainitic transformation begins to work. In this case, carbides are released.

Moreover, the oversaturation of the $\boldsymbol{\alpha}$ - phase is more significant. Therefore, solid carbides are selected in the $\boldsymbol{\alpha}$-phases crystals. This intermediate transformation is not going to the end. Austenitic steel, which has not decomposed into bainite, can be transformed in two ways of development. One way is a partial martensitic transformation.

Second is the preservation of austenitic steel (residual austenitic steel). Thus, in this case, the steel consists of three phases: martensite, lower bainite and individual areas of residual austenitic steel.

The photo (see Fig. 5,c) shows the image of the target surface, which is made of a ball, after unloading from a drum mill. The target was processed by HCEB. The thickness of the target is $0.7 \mathrm{~mm}$.

For this case, the process of converting the target surface was different from the previous one. Reason of differences is the thickness of the target. In the previous case, the target thickness was $2 \mathrm{~mm}$. The pulse of a high-current electron beam melted the surface layer of the target.

For a target with a thickness of $2 \mathrm{~mm}$, strong heat removal occurs. The cooling of the molten layer occurs quickly and with a high heat transfer coefficient.

For a target with a thickness of $0.7 \mathrm{~mm}$, due to the small mass of the substrate, the substrate is heated from the molten surface. The temperature of the substrate is not constant. It varies in a certain temperature range.

Heat transfer occurs not only due to heat transfer to the substrate body, but also due to thermal radiation. Phase and structural transformations occur according to other laws. These transformations are associated with iron polymorphism.

At high temperatures, austenite is highly saturated with carbon. The hypereutectoid conversion characteristics and the solubility of carbon in austenitic steel change with decreasing temperature.

In this case polymorphic $\boldsymbol{\gamma} \rightarrow \boldsymbol{\alpha}$ transformation passes in the rather wide interval of temperatures. 
Secondary cementite $\left(\mathbf{F e}_{3} \mathbf{C}\right)$ is released from the melt. The alloy becomes biphasic (austenite + secondary cementite). In this case, carbon is redistributed between austenite and secondary cementite. The concentration of carbon in austenite decreases when secondary cementite is released in the melt.

When the melt temperature reaches a value of $727^{\circ} \mathrm{C}$, austenite is converted to perlite. After cooling of the hypereutectoid steels, their composition changes. They consist of perlite and secondary cementite. Secondary cementite is released along the boundaries of former austenite grains. Its concentration increases when the carbon content in steel is higher.

Secondary cementite can stand out in the form of needles, plates, nets. Also, under certain conditions, it can stand out in the form of grains. This structure is implemented in our case (see Fig. 5,c).

The increase of hardness and strength characteristics of balls allows to prolong the terms of their exploitation and improve the performance of work of equipment of the power generating complex.

\section{CONCLUSIONS}

1. The irradiation of the steel surface (CGS) with HCBE was performed.

2. It was determined that the target was heated uniformly over the entire surface.

3. The characteristics of hardness and strength of the irradiated samples and unirradiated samples are investigated.

4. It was found that as a result of processing the target surface with $\mathrm{HCBE}$, an increase in the surface hardness of the samples occurred. The strength of the viscid break of the samples was increased after an irradiation.

5. Using fractographic analysis, it was found that austenite is converted to martensite or lower bainite.

6. The irradiation conditions under which carbides are possible are determined. Carbides are increase hardness.

\section{ACKNOWLEDGEMENT}

The research presented in this article was conducted by financial support of the state budget program "Support for the development the priority areas of scientific researches" (Budget Financial Code 6541230).

\section{REFERENCES}

1. E.M. Prokhorenko, V.F. Klepikov, V.V. Lytvynenko, P.A. Khaymovich, N.A. Shul'gin, A.I. Morozov. Diagnostics of processes of wear of materials of balls drum mills // Eastern European Journal of Enterprise Technologies. 2015, v. 1/5, N 73, p. 14-20.

2. Jr.S. Humphries. Principles of high current electron beam acceleration // Nuclear Instruments and Methods in Physics Research Section A: Accelerators, Spectrometers, Detectors and Associated Equipment. 1987 , v. 258, issue 3, p. 548-565.

3. E.M. Prokhorenko, V.V. Lytvynenko, O.A. Melyakova, Yu.F. Lonin, A.G. Ponomarev, V.T. Uvarov, N.A. Shul'gin, T.G. Prokhorenko, R.I. Starovoytov, A.I. Morozov, S.R. Artemev. Strengthening of the surface of steel (9XФM) exposed to a high-current electron beam // Problems of Atomic Science and Technology. 2020, N 1(125), p.167-172.

4. V.V. Bryukhovetskiy, N.I. Bazaleev, V.F. Klepikov, V.V. Litvinenko, O.E. Bryukhovetskay, E.M. Prokhorenko, V.T. Uvarov, A.G. Ponomar'ov. Features of gelation of surface of industrial aluminium alloy 6111 in the area of influence of impulsive bunch of electrons in the mode of premelting // Problems of Atomic Science and Technology. 2011, N 2(72), p. 2832.

5. C. Dong et al. Surface treatment by high current pulsed electron beam // Surface and Coatings Technology. 2003, v. 163-164, p. 620-624.

6. V.F. Klepikov, E.M. Prokhorenko, V.V. Lytvynenko, S.E. Donets, V.N. Robuk, T.G. Prokhorenko, V.T. Uvarov, A.G. Ponomarev, Yu.F. Lonin. The use of high-current relativistic electron beams for the study of the effects of ionizing radiation on materials storage RAW // Problems of Atomic Science and Technology. 2016, N 2(102), p. 72-77.

7. E.M. Prokhorenko, V.F. Klepikov, V.V. Lytvynenko, N.I. Bazaleyev, I.I. Magda, T.G. Prokhorenko, A.I. Morozov. Application of ir-radiometric diagnostics for control of vacuum connections of electrophysical installations // Problems of Atomic Science and Technology. 2018, N 1(113), p. 212-217.

8. V.F. Klepikov, E.M. Prokhorenko, V.V. Lytvynenko, A.A. Zaharchenko, M.A. Hazhmuradov. Control of macroscopic characteristics of composite materials for radiation protection // Problems of Atomic Science and Technology. 2015, N 2(96), p. 193-196.

9. V.T. Uvarov et al. Radiation acoustic control over the thermal parameter of construction materials irradiated by intense relativistic electron beam // Phys. of Part. and Nucl. Latter. 2014, v. 11, N 3, p. 274-281.

10. E.M. Prokhorenko, V.V. Lytvynenko, A.A. Zaharchenko, M.A. Hazhmuradov, T.G. Prokhorenko. Studying the changes in the characteristics of radiationprotective composition materials in dependence on homogeneity of distributing of metal components // Problems of Atomic Science and Technology. 2019, N 2(120), p. 121-126.

11. K. Maruyama et al. Strengthening mechanisms of creep resistant tempered martensitic steel // ISIJ Int. 2001, v. 41, p. 641-653.

12. J. Zou et al. Oxidation protection of AISI H13 steel by high current pulsed electron beam treatment // Surf. Coat. Technol. 2004, v. 183, p. 261-267.

13. E.M. Prokhorenko, V.F. Klepikov, V.V Lytvynenko, A.A. Zaharchenko, M.A. Khazhmuradov. Application of methods of modeling of radiationprotective characteristics of polystyrene-metal composite materials // Problems of Atomic Science and Technology. 2016, N 3(103), p. 123-127.

14. K. Zhang et al. Formation and evolution of craters in carbon steels during low-energy high-current pulsed electron-beam treatment // J. Vac. Sci. Technol. A. 2009, v. 27, p. 1217-1226.

15. E.M. Prokhorenko, V.F. Klepikov, V.V. Lytvynenko, A.A. Zaharchenko, M.A. Khazhmuradov. Performance Ratio Hardness Characteristics Polystyrene-Metal Composite Materials // Problems of 
Atomic Science and Technology. 2015, N 5(99), p. 3642.

16. T. Grosdidier et al. Texture modification, grain refinement and improved hardness/corrosion balance of a FeAl alloy by pulsed electron beam surface treatment in the "heating mode" // Scr. Mater. 2008, v. 58, p. $1058-1061$.

17. J. Zou et al. Texture and microstructure at the surface of an AISI D2 steel treated by high current pulsed electron beam // Metall. Mater. Trans. A. 2007, v. 38, p. 2061-2071.

18. Yu.M. Lakhtin, V.P. Leontieva. Material Science. M.: "Materials Science", 1990, 528 p.

19. D. Fellouz. Fraktography and Atlas of fraktograms. Ohio: "Metals park”, 1979, 489 p.

\section{МОДИФИКАЦИЯ СТРУКТУРЫ ПОВЕРХНОСТИ СТАЛИ (ХГС) В РЕЗУЛЬТАТЕ ВОЗДЕЙСТВИЯ ВЫСОКОТОЧНОГО ПУЧКА ЭЛЕКТРОНОВ}

Е.М. Прохоренко, В.В. Литвиненко, Е.А. Мелякова, Ю.Ф. Лонин, А.Г. Пономарёв, В.Т. Уваров, Н.А. Шульгин, Т.Г. Прохоренко

Поверхность стали (ХГС) была облучена сильноточным электронным пучком. Сильноточный электронный пучок получили в ускорителе ТЕМП-А. Образцы стали были изготовлены из шаров барабанной мельницы. Шары имели различную степень износа. Изучались механические и микроструктурные характеристики. Применяли методики: измерение твердости, вязкости на разрыв, фрактографический и металлографический анализы. Для всех образцов обнаружено увеличение твердости. Увеличение твердости поверхности образцов происходило в результате преобразования аустенита в мартенсит и нижний бейнит. Существенное влияние на увеличение твердости поверхности образцов также оказывает процесс появления карбидов.

\section{МОДИФІКУВАННЯ СТРУКТУРИ ПОВЕРХНІ СТАЛІ (ХГС) У РЕЗУЛЬТАТІ ДІЇ СИЛЬНОСТРУМОВОГО ПУЧКА ЕЛЕКТРОНІВ}

\section{Є.М. Прохоренко, В.В. Литвиненко, О.А. Мелякова, Ю.Ф. Лонін, А.Г. Пономарьов, В.Т. Уваров, М.А. Шульгін, Т.Г. Прохоренко}

Поверхня сталі (ХГС) була опромінена сильнострумовим електронним пучком. Сильнострумовий електронний пучок отримали в прискорювачі ТЕМП-А. Зразки сталі були виготовлені з куль барабанного млина. Кулі були різного ступеня зносу. Вивчалися механічні і мікроструктурні характеристики. Застосовували методики: вимірювання твердості, в’язкості на розривання, фрактографічний i металографічний аналізи. Для всіх зразків виявлено збільшення твердості. Збільшення твердості поверхні зразків відбувалося в результаті перетворення аустеніту в мартенсіт та нижній бейніт. Істотний вплив на збільшення твердості поверхні зразків також надає процес появи карбідів. 